\title{
10-Hydroxy-2-decenoic Acid, a Major Fatty Acid from Royal Jelly, Inhibits VEGF-induced Angiogenesis in Human Umbilical Vein Endothelial Cells
}

\author{
Hiroshi Izuta', Yuichi Chikaraishi ${ }^{1}$, Masamitsu Shimazawa', Satoshi Mishima ${ }^{2}$ and \\ Hideaki Hara ${ }^{1}$
}

${ }^{1}$ Department of Biofunctional Evaluation, Laboratory of Molecular Pharmacology, Gifu Pharmaceutical University, 5-6-1 Mitahora-higashi, Gifu 502-8585, Japan and ${ }^{2}$ Nagaragawa Research Center, API Co. Ltd, 692-3 Nagara,

Yamasaki, Gifu 502-0071, Japan

\begin{abstract}
Vascular endothelial growth factor (VEGF) is reported to be a potent pro-angiogenic factor that plays a pivotal role in both physiological and pathological angiogenesis. Royal jelly (RJ) is a honeybee product containing various proteins, sugars, lipids, vitamins and free amino acids. 10-Hydroxy-2-decenoic acid (10HDA), a major fatty acid component of RJ, is known to have various pharmacological effects; its antitumor activity being especially noteworthy. However, the mechanism underlying this effect is unclear. We examined the effect of 10HDA on VEGFinduced proliferation, migration and tube formation in human umbilical vein endothelial cells (HUVECs). Our findings showed that, 10HDA at $20 \mu \mathrm{M}$ or more significantly inhibited such proliferation, migration and tube formation. Similarly, $10 \mu \mathrm{M}$ GM6001, a matrix metalloprotease inhibitor, prevented VEGF-induced migration and tube formation. These findings indicate that 10HDA exerts an inhibitory effect on VEGF-induced angiogenesis, partly by inhibiting both cell proliferation and migration. Further experiments will be needed to clarify the detailed mechanism.
\end{abstract}

Keywords: HUVECs - migration - proliferation - tube formation

\section{Introduction}

Angiogenesis, the formation of new blood vessels from the pre-existing vasculature, is a highly regulated process that is essential for the development of multicellular organisms $(1,2)$. In the adult, angiogenesis is normally restricted and is predominantly associated with female reproductive functions and wound healing $(3,4)$. Vascular endothelial growth factor (VEGF) is a key regulator of normal and pathological angiogenesis (5-7). At the cellular level, VEGF stimulation drives multiple responses, including endothelial cell proliferation, migration,

For reprints and all correspondence: Prof. Hideaki Hara, $\mathrm{PhD}, \mathrm{RPh}$, Department of Biofunctional Evaluation, Laboratory of Molecular Pharmacology, Gifu Pharmaceutical University, 5-6-1 Mitahora-higashi, Gifu 502-8585, Japan. Tel/Fax: +81-058-237-8596;

E-mail: hidehara@gifu-pu.ac.jp survival and permeability (8). Loss of regulation of angiogenesis, resulting in uncontrolled and excessive neovascularization, contributes to the development of many pathologies, including retinopathies, rheumatoid arthritis and tumor growth $(9,10)$.

Royal jelly (RJ), the exclusive food of the larva of the queen honeybee (Apis mellifera), is secreted from the hypopharyngeal and mandibular glands of the worker honeybees mainly between the sixth and twelfth days of their life (11). RJ has been demonstrated to possess several pharmacological activities in experimental animals, including vasodilator and hypotensive activities (12), growth rate increasing activity (13), a disinfectant action (14), antitumor activity (15-17), antihypercholesterolemic activity (18) and anti-inflammatory activity (19). Chemical composition analysis has shown that RJ 
consists mainly of proteins, sugars, lipids, vitamins and free amino acids $(20,21)$. 10HDA, a major fatty acid component of RJ, has many pharmacological activities, such as antitumor activity (22), size- and lipogenesisinhibiting activity toward the hamster ear sebaceous gland (23), collagen production promoting activity (24) and antibiotic activity (25). As a consequence, RJ is widely used in commercial medical products, health foods and cosmetics in many countries. However, the mechanisms underlying these activities of RJ, especially the antitumor activity, remain unknown.

Matrix metalloproteinase (MMP) is required for migration and invasion by normal and tumor cells. We initially utilized the MMP inhibitor GM6001 to assess the effect of MMP inhibitors on thymocyte development. GM6001, a hydroxylamine-based inhibitor which inhibits many MMP with a $\mathrm{Ki}$ in the low nanomolar range, has been reported to reduce the migration of many kinds of cells (26). We used GM6001 as a positive control in the present study.

The purpose here was to evaluate the functional role of 10HDA on human pathology. A number of compounds, including valproic acid (27), sodium butyrate (28) and isomers of conjugated linoleic acid (29), are known to be angiogenesis inhibitors. Here, we examined the effects of 10HDA on VEGF-induced angiogenesis in human umbilical vein endothelial cells (HUVECs).

\section{Methods}

\section{Cells and Chemicals}

HUVECs, fibroblast cells, endothelial cell basal medium (HuMedia-EB2), fetal bovine serum (FBS), gentamycin, amphotericin B, endothelial growth factors (hEGF, hydrocortisone, hFGF-B and heparin), VEGF, mouse antihuman $\mathrm{CD} 31$ antibody, goat antimouse $\mathrm{IgG}$ alkaline phosphatase-conjugated antibody, 5-bromo-4-chloro3-indolyl phosphate/nitro blue tetrazolium (BCIP/NBT) and angiogenesis growth medium were purchased from Kurabo (Osaka, Japan). 10HDA was purchased from API Co. Ltd (Gifu, Japan), which was refined from RJ in China. GM6001 was from SIGMA-Aldrich (St. Louis, MO, USA). Collagen type I was from Kanda Gelatin Tech (Osaka, Japan). Cell Culture Kit-8 was from Dojindo (Kumamoto, Japan).

\section{Cell Cultures}

The HUVEC line is the cell model most commonly used to analyze the effects of various drugs and reagents on angiogenesis related to tumor growth and metastasis (30-32). HUVECs were cultured in HuMedia-EB2 (Kurabo) supplemented with $2 \%$ (v/v) FBS, $50 \mu \mathrm{g} / \mathrm{ml}$ gentamycin, $50 \mathrm{ng} / \mathrm{ml}$ amphotericin $\mathrm{B}$, and endothelial growth factors $(10 \mathrm{ng} / \mathrm{ml} \mathrm{hEGF}, 1 \mu \mathrm{g} / \mathrm{ml}$ hydrocortisone, $5 \mathrm{ng} / \mathrm{ml} \mathrm{hFGF-B}$ and $10 \mu \mathrm{g} / \mathrm{ml}$ heparin) at $37^{\circ} \mathrm{C}$ in a humidified atmosphere of $5 \% \mathrm{CO}_{2}$.

\section{Tube-Formation Assay}

To evaluate tube formation by endothelial cells, a HUVECs in vitro angiogenesis kit (Kurabo) was used. HUVECs and fibroblasts were co-cultured in angiogenesis growth medium supplemented with VEGF $(10 \mathrm{ng} / \mathrm{ml})$ and/or various concentrations of 10HDA $(20-500 \mu \mathrm{M})$ or a single concentration of GM6001 $(10 \mu \mathrm{M})$ at $37^{\circ} \mathrm{C}$ in a humidified atmosphere of $5 \% \mathrm{CO}_{2}$. This stimulation was repeated every 4 days. After 11 days incubation, cells were fixed with $70 \%$ ethanol, then stained with mouse antihuman CD31 antibody (1:4000) for $1 \mathrm{~h}$, and thereafter treated with goat antimouse alkaline phosphataseconjugated antibody (1:500) for $1 \mathrm{~h}$. Then, BCIP/NBT solution was applied until endothelial cells were stained deep purple. Images were collected using a digital camera (COOLPIX 4500, Nikon, Tokyo, Japan). Tube formation was estimated by measurements of joints, path, tube length and tube area using software for tube-formation analysis (Kurabo). Joints mean that two different tubes intersect each other. Path means the number of piece tubes branched from joints. Tube length means the total length joined each tube together. Tube area means the total area measured two dimensionally.

\section{Proliferation Assay}

HUVECs were seeded at $2 \times 10^{3}$ cells/well into a 96-well plate, then incubated for $24 \mathrm{~h}$ at $37^{\circ} \mathrm{C}$ in a humidified atmosphere of $5 \% \mathrm{CO}_{2}$ (33). HUVECs were rinsed twice with PBS, then exposed for $6 \mathrm{~h}$ to HuMedia-EB2 containing $2 \%$ FBS. For stimulation, $10 \mathrm{ng} / \mathrm{ml}$ VEGF and 20-500 $\mu \mathrm{M} 10 \mathrm{HDA}$ were added, and incubation continued for $72 \mathrm{~h}$. Cell proliferation was estimated by measuring cell metabolic activity using a Cell Counting Kit-8 (CCK-8) (Dojindo). CCK-8 measures the rate of living cells. WST-8, a component of CCK-8, is converted oxide form of WST-8 by metabolic activity of living cell, and oxide form of WST-8 shows orange color.

\section{In Vitro Wound-healing Assay}

An in vitro wound-healing assay was performed to measure unidirectional migration by HUVECs (34). HUVECs were seeded at $4 \times 10^{4}$ cells/well into a 12 well plate, incubated for $48 \mathrm{~h}$ at $37^{\circ} \mathrm{C}$ in a humidified atmosphere of $5 \% \mathrm{CO}_{2}$, then washed with PBS twice and incubated in Humedia-EB2 with $1 \%$ FBS. After $24 \mathrm{~h}$ incubation, the monolayers of HUVECs were scratch wounded to a $1 \mathrm{~mm}$ depth in a straight line using a 10-200 $\mu \mathrm{l}$ micro-tip. For stimulation, VEGF $(10 \mathrm{ng} / \mathrm{ml})$ and/or 10HDA $(500 \mu \mathrm{M})$ or GM6001 $(10 \mu \mathrm{M})$ were 
added, and incubation continued for $24 \mathrm{~h}$. Images were taken at the time of the wounding and at 24-h intervals thereafter using a phase-contrast microscope (OLYMPUS, Tokyo, Japan). Migration was estimated by counting the cell numbers within the wounded region. Invading cells were counted in a masked fashion by a single observer (H. I.), and taken as migrating cells. For each monolayer sample, four measurements were taken from four fields in each of three independent wounds.

\section{Statistical Analysis}

Data are presented as means \pm SEM Statistical comparisons were made using a one-way ANOVA followed by a Student's $t$-test, using STAT VIEW version 5.0 (SAS Institute, Inc., Cary, NC, USA). A value of $P<0.05$ was considered to indicate statistical significance.

\section{Results}

VEGF-induced Tube Formation in HUVECs was Suppressed by 10HDA

We first investigated the effects of 10HDA on endothelial tube formation. HUVECs and fibroblasts were co-cultured with VEGF $(10 \mathrm{ng} / \mathrm{ml})$ and/or various concentrations of 10HDA $(20-500 \mu \mathrm{M})$ or GM6001 $(10 \mu \mathrm{M})$. After 11days incubation, endothelial cells were stained with anti-CD31 antibody. When treated with VEGF, HUVECs became organized into complex tubular networks (Fig. 1A). All tube-formation parameters (joints, path, tube length and tube area) were increased more than 2-fold by VEGF treatment (vs. control) (Fig. 1B). 10HDA decreased VEGF-induced tube formation significantly in a concentration-dependent manner. 10HDA at $20 \mu \mathrm{M}$ or more inhibited the joints and path parameters of VEGF-induced tube formation, while 10HDA at $500 \mu \mathrm{M}$ inhibited tube length. However, 10HDA did not affect tube area at any concentration. On the other hand, GM6001 at $10 \mu \mathrm{M}$ significantly decreased all tubeformation parameters. We observed scattered fragments stained with anti-CD31 antibody in results of tubeformation assay. The fragments were included in each one out of five samples in VEGF treatment group, VEGF and $20 \mu \mathrm{M} 10 \mathrm{HDA}$ treatment group, VEGF and $500 \mu \mathrm{M} 10 \mathrm{HDA}$ treatment group. The fragments may be artifact and we could not explain it, and therefore we excluded these data included scattered fragments from statistical processing on in vitro tube-formation assay.

\section{HDA Prevented Cell Proliferation in HUVECs}

Next, we examined whether 10HDA inhibits cell proliferation in HUVECs. As shown in Fig. 2, treatment with VEGF $(10 \mathrm{ng} / \mathrm{ml})$ induced HUVEC proliferation, the cell count being two times more than in control. $10 \mathrm{HDA}$ at $500 \mu \mathrm{M}$ inhibited this VEGF-induced cell proliferation significantly, however $20-100 \mu \mathrm{M}$ 10HDA did not inhibit the cell proliferation.

\section{HDA Suppressed Migration in a Wound-healing Assay}

To investigate whether 10HDA inhibits the migration of HUVECs, we performed a wound-healing assay under 1\% FBS conditions (Fig. 3A). Briefly, after starvation, HUVECs were scratch wounded and treated with VEGF $(10 \mathrm{ng} / \mathrm{ml})$ with or without $10 \mathrm{HDA}(500 \mu \mathrm{M})$ or GM6001 $(10 \mu \mathrm{M})$. VEGF increased the number of migrated cells 1.76-fold (vs. control). 10HDA and GM6001 reduced this migration to $86.0 \pm 2.3 \% \quad(n=6) \quad$ and $82.1 \pm 4.6 \%$ $(n=6)$, respectively, of the value obtained in the presence of VEGF (Fig. 3B). However, in the cell migration assay, we detected no abnormalities with 10HDA or GM6001 alone.

\section{Discussion}

In the present study, we showed that $10 \mathrm{HDA}$ at $20 \mu \mathrm{M}$ or more inhibited VEGF-induced migration, proliferation and tube formation in HUVECs. On the tube formation assay, it was expected that 10HDA mainly inhibited cell migration, because 10HDA inhibited the developmental step included joints and path and the lengthen step included tube length. 10HDA at $500 \mu \mathrm{M}$ suppressed both cell migration (as did GM6001) and proliferation in HUVECs. These findings indicate that 10HDA may inhibit the VEGF-induced angiogenesis, partly by inhibiting cell migration and proliferation.

In the present study, we used GM6001, a positive control antiangiogenesis compound, and indeed GM6001 at $10 \mu \mathrm{M}$ inhibited both migration and tube formation in HUVECs. As far as we know, any one did not report about the effects that 10HDA inhibits MMP, however the effects of 10HDA resembled very much with those of GM6001 on cell migration and in vitro tube formation assay. Therefore, we cannot rule out the possibility that 10HDA may inhibit MMPs, likely GM6001.

Angiotensin II, which is produced by angiotensin converting enzyme (ACE), causes hypertension by constricting resistance vessels. RJ peptides [Ile-Tyr (IY), Val-Tyr (VY), Ile-Val-Tyr (IVY)] have been reported to exhibit vasodilator and hypotensive activities via inhibition of ACE (35). Since angiotensin II stimulates angiogenesis (36) and the migration of retinal microvascular pericytes (37), RJ might be expected to inhibit angiogenesis by inhibiting angiotensin II. Therefore, it will be interesting to study whether 10HDA can inhibit angiotensin II. In the present study, 10HDA inhibited angiogenesis (tube formation in HUVECs), suggesting 
A
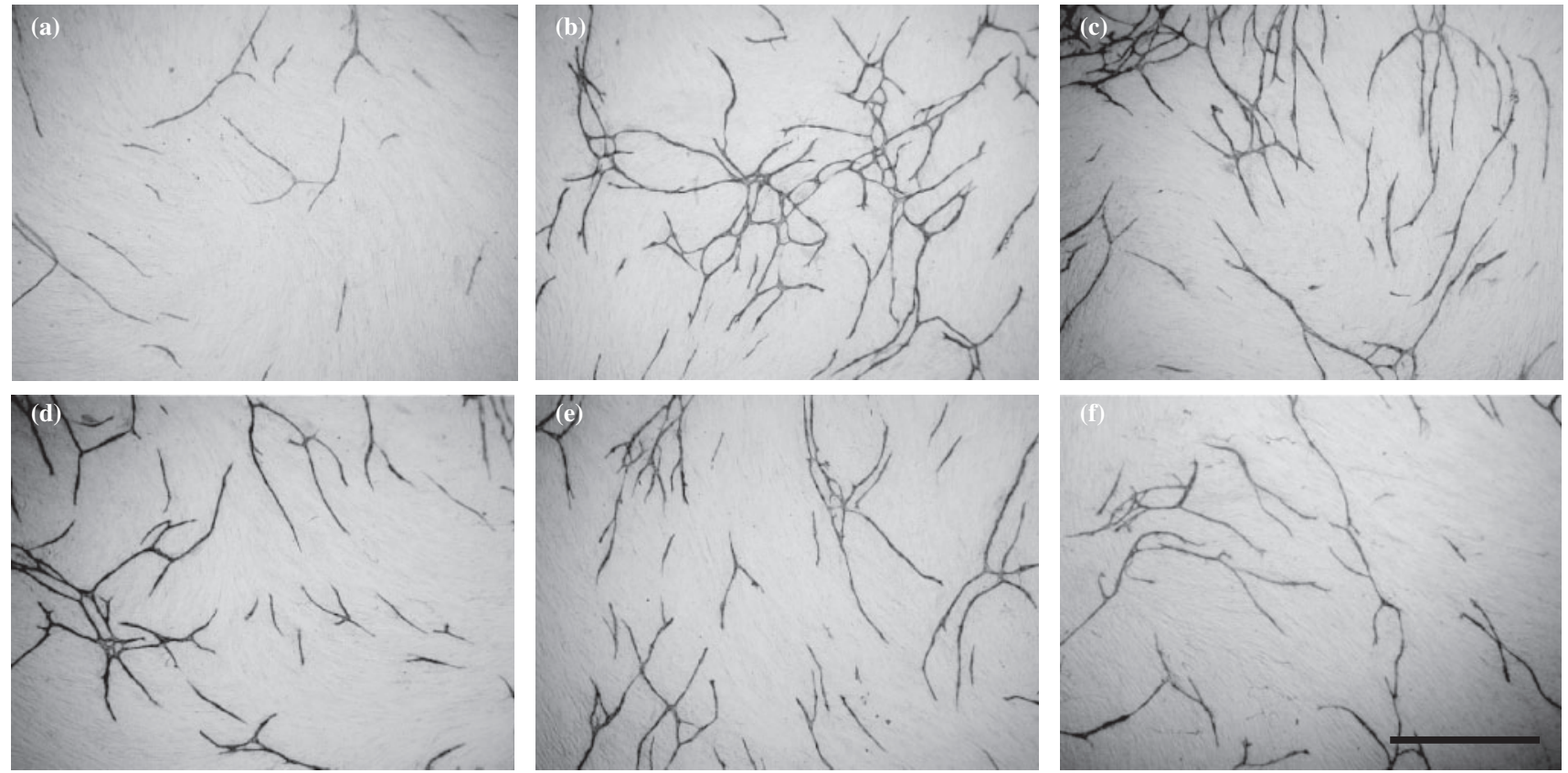

B
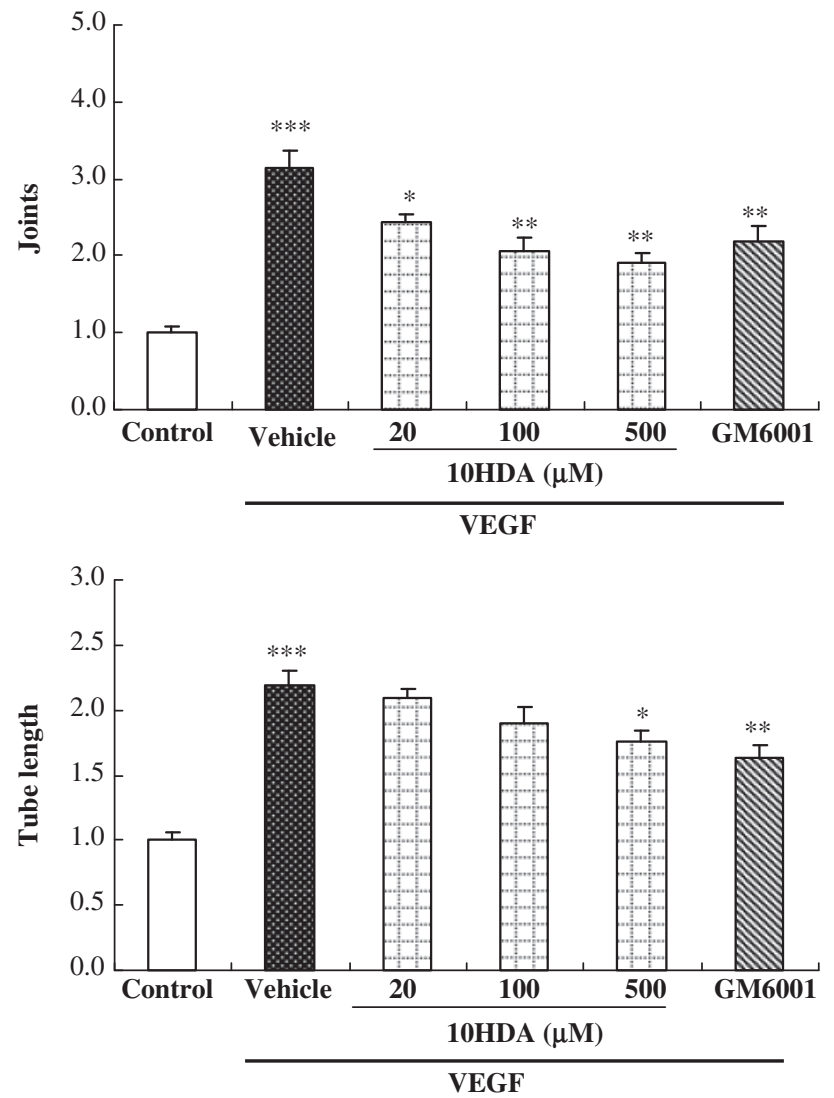

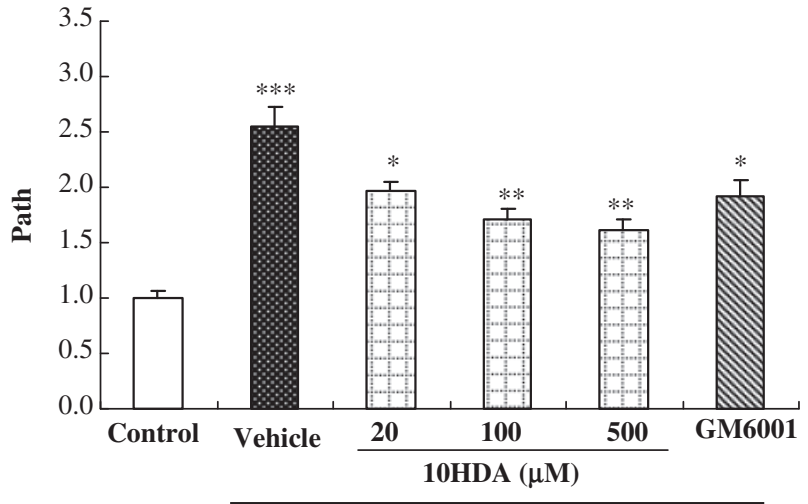

VEGF

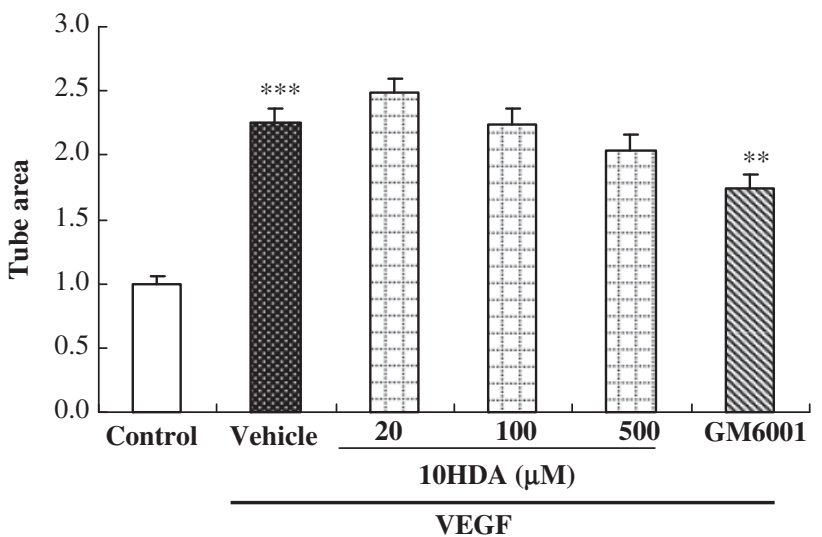

Figure 1. 10HDA and MMP inhibitor prevented in vitro tube formation in HUVECs. (A) In vitro tube formation was achieved using an in vitro angiogenesis kit. Briefly, HUVECs and fibroblasts were incubated with VEGF $(10 \mathrm{ng} / \mathrm{ml})$ (b-f), together with $10 \mathrm{HDA}(20 \mu \mathrm{M})$ (c), $10 \mathrm{HDA}$ $(100 \mu \mathrm{M})(\mathrm{d}), 10 \mathrm{HDA}(500 \mu \mathrm{M})(\mathrm{e})$, or GM6001 $(10 \mu \mathrm{M})(\mathrm{f})$. Then 11 days afterwards, they were stained with anti-CD31 antibody, an endothelial cell marker. Control is shown in (a). Scale bar represents $1 \mathrm{~mm}$. (B) Tube formation was evaluated by measurements of joints, path, tube length and tube area, as described in 'Methods'. Data represent means and standard error $(n=5)$. ***P<0.01 vs. control; $* P<0.05$, ** $P<0.01$ vs. vehicle (Student's $t$-test). 


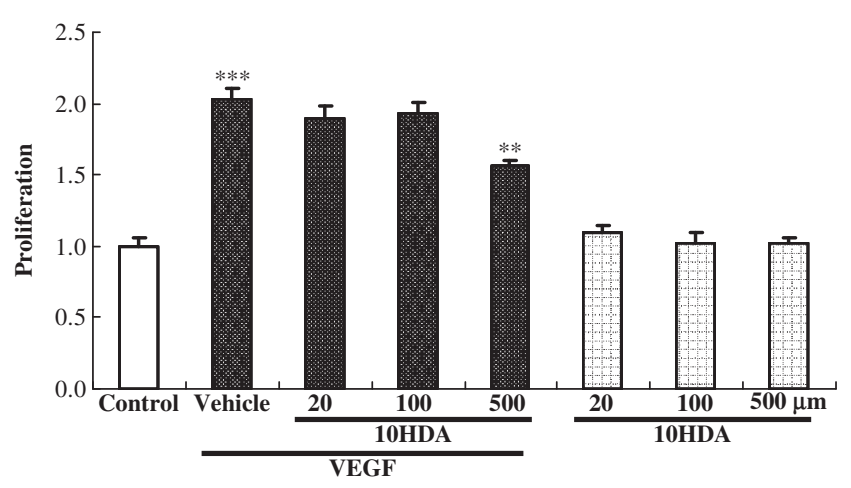

Figure 2. 10HDA prevented VEGF-induced cell proliferation in HUVECs. HUVECs were incubated with the indicated concentrations of 10HDA in the presence or absence of VEGF $(10 \mathrm{ng} / \mathrm{ml})$ for 3 days at $37^{\circ} \mathrm{C}$ in $5 \% \mathrm{CO}_{2}$ with humidity. Cell proliferation was estimated using a CCK-8. VEGF treatments increased cell viability 2-fold (vs. control). $10 \mathrm{HDA}$ at $500 \mu \mathrm{M}$ had no effect by itself, yet inhibited VEGF-induced proliferation. Data represent means and standard error $(n=6)$. *** $P<0.01$ vs. control, $* * P<0.01$ vs. vehicle (Student's $t$-test).

that RJ (which contains 10HDA) could be a useful food for diseases involving angiogenesis.

We performed this study under restricted conditions, angiogenesis being examined by evaluating VEGFinduced tube formation in HUVECs. However, actual angiogenesis is much more complex. Pro-angiogenic proteins such as VEGF, fibroblast growth factor (FGF) and angiopoietin-1 are balanced by antiangiogenic proteins such as angiopoietin 2, endostatin and tissue inhibitor of metalloproteinases-1 (TIMP-1). When this regulation is eliminated or disrupted in such a way that excessive neovascularization occurs, this may contribute to the development of tumor growth. Therefore, for a proper evaluation of the relationship between the antiangiogenesis and antitumor growth effects of 10HDA, future experiments will need to study the effects of RJ and 10HDA on in vivo angiogenesis models.

In conclusion, this is the first report that 10HDA inhibits in vitro angiogenesis in HUVECs, in part due to its inhibition of both cell proliferation and migration.

\section{Acknowledgements}

The present work is supported by a grant from the Royal Jelly Fair Trade Council (Japan). We thank Drs Yoko Araki and Takashi Sakamoto, API Research Center, for useful advice, and $\mathrm{Mr}$ Nozomi Matsunaga for technical support.

\section{References}

1. Risau W. Mechanisms of angiogenesis. Nature 1997;386:671-4.

2. Yancopoulos GD, Davis S, Gale NW, Rudge JS, Wiegand SJ, Holash J. Vascular-specific growth factors and blood vessel formation. Nature 2000;407:242-8.
A
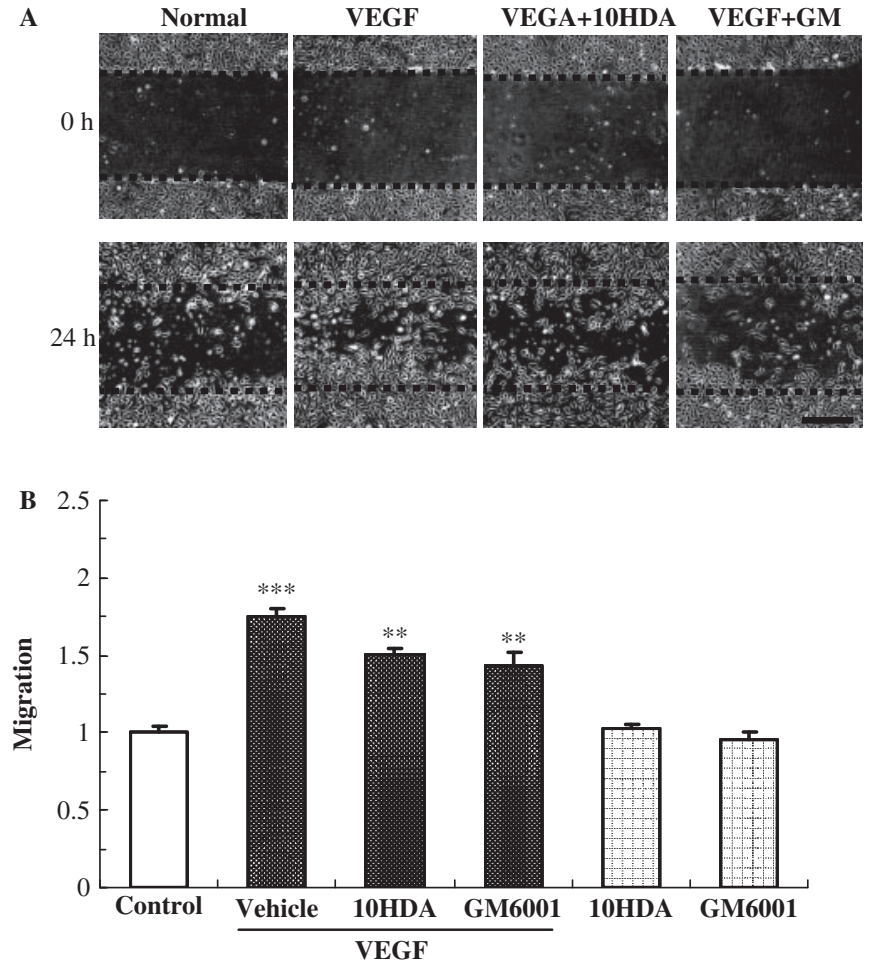

Figure 3. 10HDA suppressed cell migration on in vitro wound-healing assay. HUVECs migration was assessed using a wound-healing assay. Briefly, $90 \%$ confluent monolayers of HUVECs were scratch wounded, and then incubated for $24 \mathrm{~h}$. (A) Images of wounded monolayer of HUVECs taken at times $0 \mathrm{~h}$ and $24 \mathrm{~h}$ after treatment with VEGF $(10 \mathrm{ng} / \mathrm{ml})$ with or without 10HDA $(500 \mu \mathrm{M})$ or GM6001 $(10 \mu \mathrm{M})$. The horizontal lines indicate the wound edge. Wound closure in response to VEGF stimulation was reduced by addition of 10HDA or GM6001. Scale bar represents $500 \mu \mathrm{m}$. (B) Migration was estimated by measurement of cell numbers within the wounded region. 10HDA and GM6001 had no effects by themselves, yet decreased VEGF-induced migration (vs. vehicle). Data represent means and standard error $(n=6)$. *** $P<0.01$ vs. control, ${ }^{* *} P<0.01$ vs. vehicle (Student's $t$-test).

3. Autiero M, Waltenberger J, Communi D, Kranz A, Moons L, Lambrechts D, et al. Role of PIGF in the intra- and inter-molecular cross talk between the VEGF receptors Flt1 and Flk1. Nat Med 2003;9:936-43

4. Folkman J, Klagsbrun M. Angiogenic factors. Science 1987;235:442-7.

5. Ferrara N, Alitalo K. Clinical applications of angiogenic growth factors and their inhibitors. Nat Med 1999;5:1359-64.

6. Kerbel RS. Tumor angiogenesis: past, present and the near future. Carcinogenesis 2000;21:505-15.

7. Ferrara N. Vascular endothelial growth factor. Basic science and clinical progress. Endocr Rev 2004;25:581-611.

8. Zachary I. VEGF signaling: integration and multi-tasking in endothelial cell biology. Biochem Soc Trans 2003;31:1171-7.

9. Folkman J. Angiogenesis in cancer, vascular, rheumatoid and other disease. Nat Med 1995;1:27-31.

10. Carmeliet P, Jain RK. Angiogenesis in cancer and other diseases. Nature 2000;407:249-57.

11. Patel NG, Haydak MH, Gochnauer TA. Electrophoretic components of the proteins in honeybee larval food. Nature 1960;186: 633-4.

12. Shinoda M, Nakajin S, Oikawa T, Sato K, Kamogawa A, Akiyama Y. Biochemical studies on vasodilative factor in royal jelly [in Japanese]. Yakugaku Zasshi 1978;98:139-45.

13. Kawamura J. Influence of gelee royale on embryos [in Japanese]. J Showa Med Assoc 1961;20:1465-71. 
14. Yatsunami K. Echigo T. Antibacterial action of royal jelly. Bull Fac Agr Tamagawa Univ 1985;25:13-22.

15. Tamura T, Fujii A, Kuboyama N. Antitumor effect of royal jelly [in Japanese]. Folia Pharmacol Japon 1987;89:73-80.

16. Townsend GF, Morgan JF, Hazlett B. Activity of 10-hydroxydecenoic acid from royal jelly against experimental leukemia and ascetic tumors. Nature 1959;183:1270-1.

17. Townsend GF, Morgan JF, Tolnai S, Hazlett B, Morton HJ, Shuel RW. Studies on the in vitro antitumor activity of fatty acids I. 10-hydroxy-2-decenoic acid from royal jelly. Cancer Res 1960;20:503-10.

18. Nakajin S, Okiyama K, Yamashita S, Akiyama Y, Shinoda M. Effect of royal jelly on experimental hypercholesterolemia in rabbits [in Japanese]. Yakugaku Zasshi 1982;36:65-9.

19. Fujii A, Kobayashi S, Kuboyama N, Furukawa Y, Kaneko Y, Ishihama S, et al. Augmentation of wound healing by royal jelly (RJ) in streptozotocin-diabetic rats. Jp J Pharmacol 1990;53:331-7.

20. Takenaka T. Chemical composition of royal jelly. Honeybee $\mathrm{Sci}$ 1982;3:69-74.

21. Echigo T, Takenaka T, Yatsunami K. Comparative studies on chemical composition of honey, royal jelly and pollen loads. Bull Fac Agr Tamagawa Univ 1986;26:1-12.

22. Townsend GF, Brown WH, Felauer EE, Hazlett B. Studies on the in vitro antitumor activity of fatty acids. The esters of acids closely related to 10-hydroxy-2-decenoic acid from royal jelly against transplantable mouse leukemia. Can $J$ Biochem Physiol 1961;39:1765-70.

23. Maeda T, Kuroda H, Motoyoshi K. Effects of royal jelly and 10-hydroxy decenoic acid on the sebaceous glands of hamster ear. Jpn J Dermatol 1987;98:469-75.

24. Koya-Miyata S, Okamoto I, Ushio S, Iwaki K, Ikeda M, Kuramoto M. Identification of a collagen production-promoting factor from an extract of royal jelly and its possible mechanism. Biosci Biotechnol Biochem 2004;68:767-73.

25. Blum MS, Novak AF, Taber S III. 10-Hydroxy-2-decenoic acid, an antibiotic found in royal jelly. Science 1959;130:452-3.

26. Daniela P, Silvia P, Valentina U, GianLuigi C, Paola M. Pro-collagen I COOH-terminal trimer induces directional migration and metalloproteinases in breast cancer cells. J Biochem 2003;278: 3639-47.
27. Martin MU, Ruth M, Ingrid F, Tatyana S, Jaroslav C, Roman AB, et al. Valproic acid inhibits angiogenesis in vitro and in vivo. $J$ Nutr 2004; 134:299-307.

28. Samid D, Shack S, Sherman LT. Phenylacetate: a novel nontoxic inducer of tumor cell differentiation. Cancer Res 1992;52:1988-92.

29. Patricia AM, Danilo Z, Clemet I, Mary MV, Suzanne FS, Sibel OM, et al. Isomers of conjugated linoleic acid differ in their effects on angiogenesis and survival of mouse mammary adipose vasculature. J Nutr 2004;134:299-307.

30. Wright TJ, Leach L, Shaw PE, Jones P. Dynamics of vascular endothelial-cadherin and beta-catenin localization by vascular endothelial growth factor-induced angiogenesis in human umbilical vein cells. Exp Cell Res 2002;280:159-68.

31. Lin MT, Yen ML, Lin CY, Kuo ML. Inhibition of vascular endothelial growth factor-induced angiogenesis by resveratrol through interruption of Src-dependent vascular endothelial cadherin tyrosine phosphorylation. Mol Pharmacol 2003;64:1029-36.

32. Beecken WD, Engl T, Hofmann J, Jonas D, Blaheta R. Clinical relevance of serum angiogenic activity in patients with transitional cell carcinoma of the bladder. J Cell Mol Med 2005;9:655-61.

33. Oak JH, Nakagawa K, Oikawa S, Miyazawa T. Amadori-glycated phosphatidylethanolamine induces angiogenic differentiations in cultured human umbilical vein endothelial cells. FEBS Lett 2003;555:419-23.

34. Meghna UN, Ulhas PN. Junctional adhesion molecule-A-induced endothelial cell migration on vitronectin is integrin $\alpha \beta$ specific. J Cell Sci 2005;119:490-9.

35. Tokunaga KH, Yoshida C, Suzuki KM, Maruyama H, Futamura Y, Araki Y, et al. Antihypertensive effect of peptides from royal jelly in spontaneously hypertensive rats. Biol Pharm Bull 2004;27:189-92.

36. Tamarat R, Silvestre JS, Durie M, Levy BI. Angiotensin II angiogenic effect in vivo involves vascular endothelial growth factor- and inflammation-related pathways. Lab Invest 2002;82: $747-56$.

37. Nadal JA, Scicli GM, Carbini LA, Scicli AG. Angiotensin II stimulates migration of retinal microvascular pericytes: involvement of TGF-beta and PDGF-BB. Am J Physiol Heart Circ Physiol 2002;282:739-48.

Received February 19, 2007; accepted August 15, 2007 


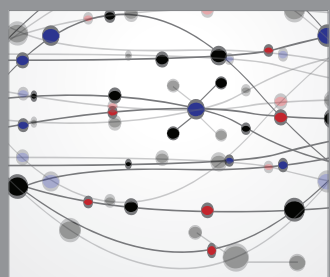

The Scientific World Journal
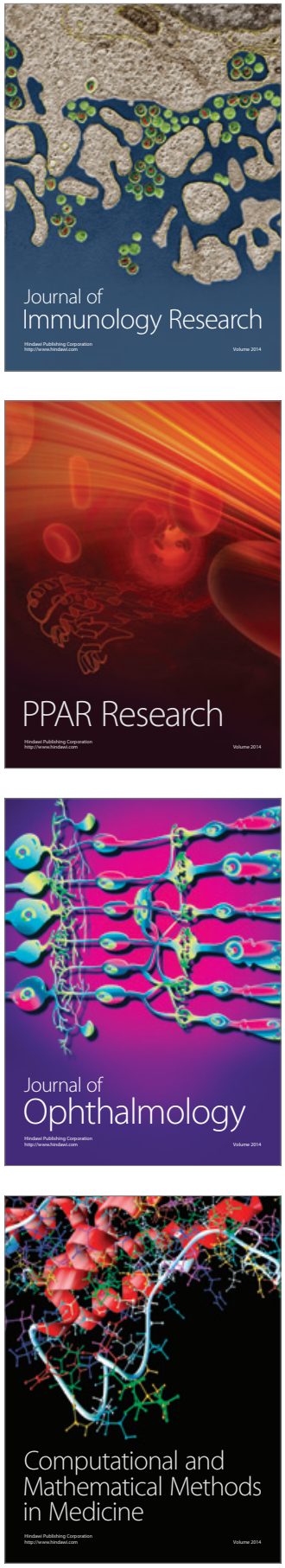

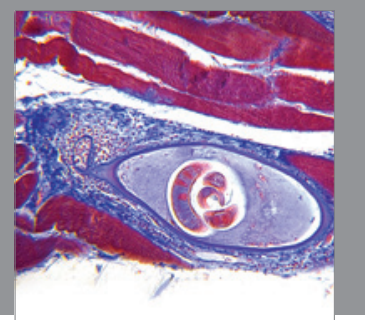

Gastroenterology

Research and Practice
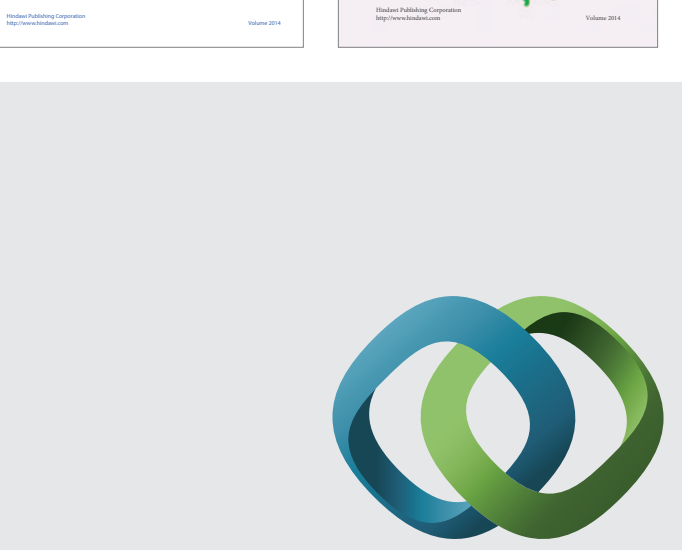

\section{Hindawi}

Submit your manuscripts at

http://www.hindawi.com
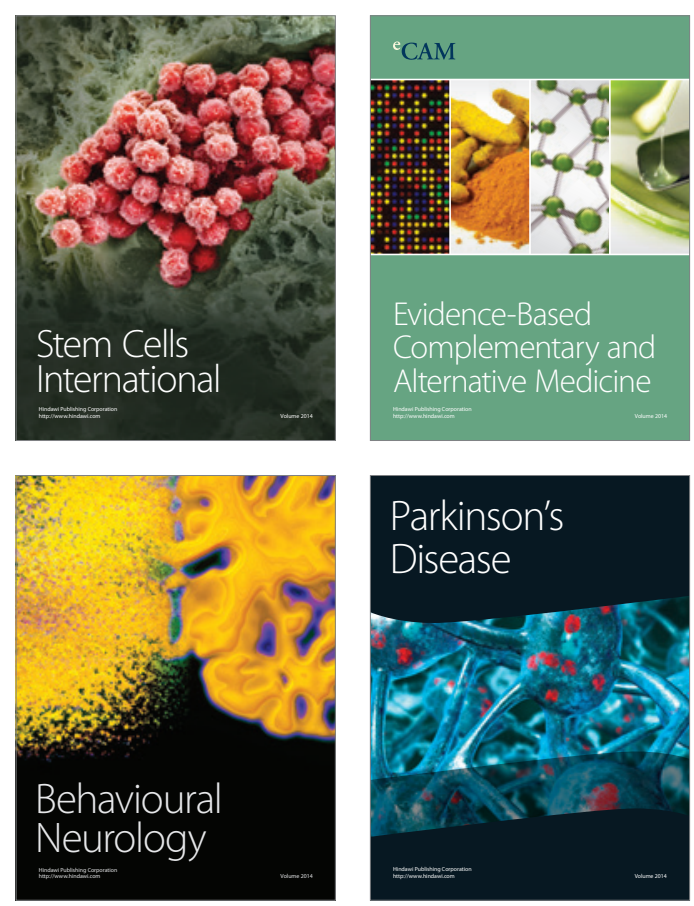

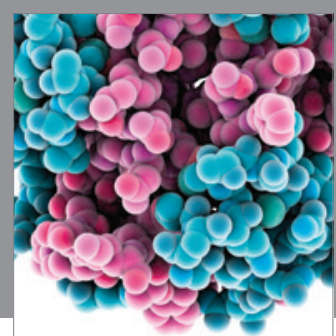

Journal of
Diabetes Research

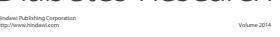

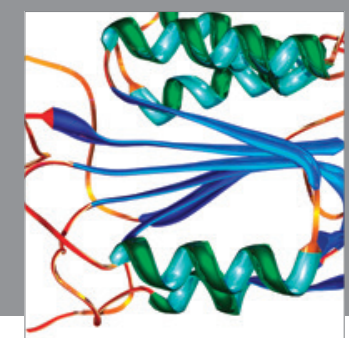

Disease Markers
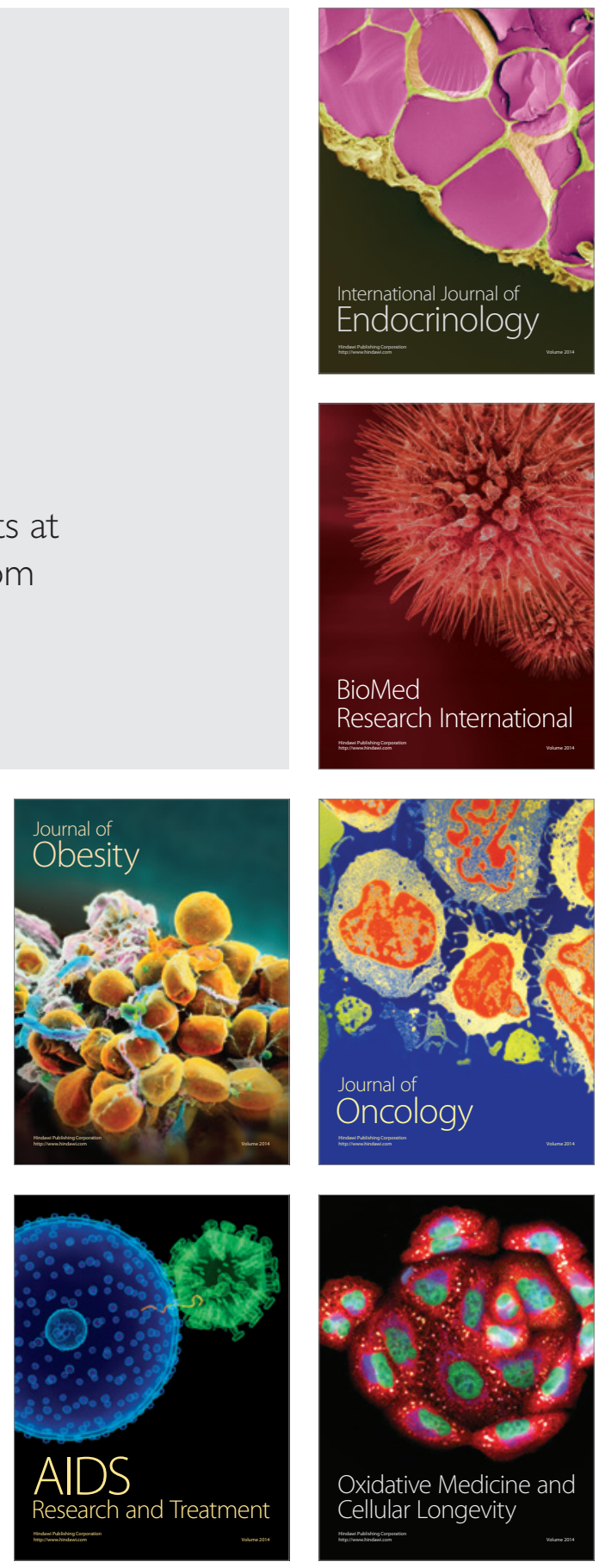